\title{
MODEL PEMBELAJARAN CONTEXTUAL TEACHING AND LEARNING (CTL) DALAM PEMBELAJARAN SEJARAH
}

\author{
Muhammad Putra Wahyu Perdana \\ Program Studi Pendidikan Sejarah FKIP Universitas Lambung Mangkurat \\ putrawahyumuhammad@gmail.com
}

\begin{abstract}
Abstrak:
Berbicara tentang Hasil belajar sejarah tidak hanya berkaitan dengan aspek pengetahuan saja. Peserta didik sudah selaknya merasakan kebermaknaan sejarah bagi diri mereka. Disamping mengenai fakta-fakta sejarah yang disajikan dalam bentuk permasalahan yang problematis, pembelajaran sejarah juga perlu dikemas dengan memperhatikan nilai-nilai. Peserta didik diharapkan mampu mengambil nilai dari sebuah peristiwa sejarah kemudian mereka dapat mempertimbangkan nilai tersebut apakah cocok bagi diri mereka. Pembelajaran sejarah yang demikian itu nantinya akan berguna bagi peserta didik sebagai bahan pertimbangan untuk bertindak. Tulisan ini akan menggambarkan pembelajaran sejarah yang melibatkan aspek nilai yaitu dengan pembelajaran sejarah berbasis nilai yang kontekstual melalui model pembelajaran CTL (Contextual Teaching And Learning). Model pembelajaran ini memberikan kesempatan bagi peserta didik untuk menemukan, dan menganalisis nilai dan mampu mengaitkan dengan keadaan yang kontekstual pada setiap peristiwa sejarah. Peserta didik tidak hanya sekedar dihadapkan pada fakta sejarah melainkan juga dituntut untuk menemukan nilai yang kontekstual Terlebih dapat menentukan apakah nilai tersebut masih relevan bagi dirinya dan keadaan zaman sekarang.
\end{abstract}

Kata Kunci: Model Pemnelajaran, Contxtual Teaching and Learning (CTL), Pembelajaran Sejarah

\section{PENDAHULUAN}

Dewasa ini penyelenggaran pembelajaran sejarah di sekolah masih terus mengalami inovasi. Berbagai macam penelitian berkaitan dengan pembelajaran sejarah masih terus dilakukan demi tercapainya tujuan pembelajaran sejarah. Tujuan pembelajaran sejarah di sekolah tidak hanya berkaitan dengan kemampuan siswa untuk menguasai materi sejarah. Masih ada aspek afektif dan psikomotorik yang juga harus diperhatikan oleh guru sejarah. Namun hal ini yang justru sering kali dilupakan. Selama ini praktek pembelajaran sejarah di sekolah masih cenderung pada proses transfer informasi. Meskipun suasana pembelajaran yang dirancang oleh guru mengharuskan peran aktif dari peserta didik, tetap saja semua itu hanya berkaitan 
dengan ketercapaian kemampuan dalam ranah pengetahuan saja. Pembelajaran sejarah yang dirancang belum sampai pada kebermaknaan dan kebermanfaatan pada diri peserta didik. Selain itu, apabila kita berbicara tentang pembelajaran Sejarah, pasti Identik dengan anggapan bahwa Pelajaran Sejarah itu kurang menarik (Putri Nur Ekasari, 2017: 192-193).

Ada beberapa faktor yang diduga mengakibatkan kondisi tersebut, antara lain : 1) anggapan yang keliru dalam diri siswa bahwa pelajaran IPS-Sejarah hanya berupa hafalan saja, 2) model dan metode pembelajaran yang dikembangkan oleh guru masih bersifat indoktrinatif dan teacher dominated, 3) materi pelajaran yang terlalu sarat dengan fakta, peristiwa dan konsep yang tersaji secara kronologis sehingga tidak menantang siswa, 4) kemampuan evaluasi yang sementara masih berkonsentrasi pada pengukuran kognitif saja. Pengajaran sejarah pada setiap tingkatan seharusnya mempunyai pendekatan yang berbeda sehingga tidak membosankan akibat banyaknya kesamaan dan pengulangan. Untuk tingkat SMU, pengajaran sejarah sebaiknya diberikan secara kritis mengingat peserta didik sudah mampu bernalar. Peserta didik diharapkan sudah bisa berpikir mengapa sesuatu terjadi, apa sebenarnya yang terjadi dan kemana arah kejadian-kejadian tersebut (Jenny K. Matitaputty, 2016: 168).

Menurut Alfian (dalam Nur Ahyani, 2013: 97) Tidak dipungkiri bahwa pendidikan sejarah mempunyai fungsi sangat dalam membentuk kepribadian bangsa, kualitas manusia dan masyarakat Indonesia pada umumnya. Tetapi sampai saat ini masih terus dipertanyakan keberhasilannya, mengingat fenomena kehidupan berbangsa dan bernegara Indonesia khususnya generasi muda makin diragukan eksistensinya. Dengan kenyataan tersebut artinya ada sesuatu yang harus dibenahi dalam pelaksanaan pembelajaran sejarah.Selain itu, masih banyak guru sejarah tidak memiliki jiawa kreatif dan inovatif. Dalam memilih model pembelajaran, walapun Kurikulum 2013 mengharuskan peserta didik itu sendiri yang mencari informasi tersebut dan guru hanya sebagai fasilitator.

Namun kenyataannya adalah banyak sekali guru yang masih menggunakan sistem pembelajaran yang terpusat pada guru itu sendiri atau teacher centered learning sehingga terjadi komunikasi satu arah. Di sini ilmu di transfer secara drill sehingga daya serap dari peserta didik lemah karena hanya mendengarkan dari guru. Oleh sebab itu pembelajaran sejarah menjadi tidak menarik dan terkesan membosankan. Tulisan ini membahas model pembelajaran inovatif yang sesuai dengan kurikulum 2013 yaitu Model Pembelajaran CTL (Contextual, Teaching and Learning) yang bisa menjadi bahan rujukan bagi para guru-guru diluar sana 
khususnya guru Sejarah untuk mengganti model pembelajarannya menjadi model pembelajaran yang inovatif dan kreatif.

\section{PEMBELAJARAN SEJARAH}

Sebelum masuk lebih dalam tentang Model Pembelajaran Sejarah, kita harus mengetahui terlebih dahulu tentang Pembelajaran Sejarah supaya kita dapat membangun paradigma yang sistematis sehingga lebih memudahkan kita untuk memahami mengenai Model Pembelajaran Sejarah. Dalam buku Heri Susanto (2014: 56-57) bahwa Pembelajaran merupakan jantung dari proses pendidikan. Pembelajaran menjadi sangat penting karena dalam kegiatan inilah terdapat proses interaksi antara guru sebagai pembawa pesan/ide dan siswa sebagai penerima pesan/ide. Dengan pandangan ini nampaklah bahwa pembelajaran merupakan wahana transformasi dan regenerasi budaya dari suatu generasi ke generasi berikutnya.

Arti penting pembelajaran ini memberikan penjelasan bahwa pembelajaran merupakan proses yang tidak bisa dianggap remeh dalam proses kemajuan suatu bangsa. Dalam pembelajaran sejarah, peran penting pembelajaran terlihat jelas bukan hanya sebagai proses transfer ide, akan tetapi juga proses pendewasaan peserta didik untuk memahami identitas, jati diri dan kepribadian bangsa melalui pemahaman terhadap peristiwa sejarah. Dengan demikian pembelajaran sejarah hendaknya memperhatikan beberapa prinsip:

1. Pembelajaran yang dilakukan haruslah adaptif terhadap perkembangan peserta didik dan perkembangan zaman. Kendatipun sejarah bercerita tentang kehidupan pada masa lalu, bukan berarti sejarah tidak bisa diajarkan secara kontekstual. Banyak nilai dan fakta sejarah yang bila disampaikan dengan benar dan sesuai dengan alam fikiran peserta didik akan mampu membangkitkan pemahaman dan kesadaran peserta didik terhadap nilai-nilai nasionalisme, patriotisme dan persatuan.

2. Pembelajaran sejarah hendaklah berorientasi pada pendekatan nilai. Menyampaikan fakta memang sangat penting dalam pembelajaran sejarah, akan tetapi yang juga tidak kalah penting adalah bagaimana mengupas faktafakta tersebut dan mengambil intisari nilai yang terdapat di dalamnya sehingga si pembelajar akan menjadi lebih mawas diri sebagai akibat dari pemahaman nilai tersebut.

3. Strategi pembelajaran yang digunakan hendaklah tidak mematikan kreatifitas dan memaksa peserta didik hanya untuk menghafal fakta dalam buku teks. Sejarah sudah saatnya diajarkan dengan cara yang berbeda, kebekuan pembelajaran yang terjadi seringkali dikarenakan rendahnya kreatifitas dalam 
pembelajaran sejarah. Sebagai akibatnya kejenuhan seringkali menjadi faktor utama yang dihadapi guru dalam mengajarkan sejarah dan siswa dalam belajar sejarah.

Dari ketiga hal tersebut dapat dipahami bahwa tantangan guru dalam mengajarkan sejarah menjadi tidak mudah. Pengajar harus memahami betul apa tujuan, karakteristik dan sasaran pembelajaran sejarah. Pengajar juga harus memahami visi dan misi pendidikan sehingga sejarah yang diajarkan dapat memberi pencerahan dan landasan berfikir dalam bersikap bagi peserta didik pada zamannya. Adapun tujuan pembelajaran sejarah Menurut Moh. Ali yang dimuat (dalam Heri Susanto, 2014: 57) pembelajaran sejarah nasional mempunyai tujuan:

1. Membangkitkan, mengembangkan serta memelihara semangat kebangsaan;

2. Membangkitkan hasrat mewujudkan cita-cita kebangsaan dalam segala lapangan;

3. Membangkitkan hasrat-mempelajari sejarah kebangsaan dan mempelajarinya sebagai bagian dari sejarah dunia;

4. Menyadarkan anak tentang cita-cita nasional (Pancasila dan Undang-undang Pendidikan) serta perjuangan tersebut untuk mewujudkan cita-cita itu sepanjang masa.

Selain itu, Pembelajaran sejarah di sekolah dilaksanakan sesuai kehendak kurikulum pendidikan nasional sebagai pelaksanaan dari Undang-Undang No. 20 Tahun 2003 tentang Sistem Pendidikan Nasional. Tujuan utama pendidikan dan pengajaran sejarah ialah untuk membantu para siswa agar mengembangkan pemahaman dan wawasan sejarah, yakni : 1) memahami perilaku manusia masa lampau; 2) memahami perilaku manusia dewasa ini, sehingga mampu; 3) merencanakan keadaan masyarakat yang akan datang dengan lebih baik.4 Artinya pembelajaran sejarah di sekolah diharapkan mampu memberikan bekal sikap melalui peristiwa-peristiwa masa lampau.

Pembelajaran sejarah menjadi amat bermakna jika guru dan pelajar memahami konteks peristiwa dan pemikiran yang muncul daripada satusatu peristiwa sejarah agar dapat dikembangkan secara lebih mendalam sebagai asas perbincangan dan analisis berstruktur sehingga iktibar dan pengajaran boleh diambil sebagai satu panduan. Hal ini nampaknya masih kurang diberikan penekanan malah guru-guru sejarah di sekolah tidak peka dengan keadaan ini, sehingga menjadikan pelajaran sejarah sebagai satu sesi pembacaan buku teks dan membuat nota semata-mata. Situasi seperti ini menjadikan proses instruksional berjalan pasif dan tidak bermaya. Oleh sebab itu, sudah tiba masanya pendekatan pengajaran sejarah berubah agar tidak 
lagi dilabel pasif, membosankan dan tidak hidup. Untuk menjadikan pengajaran Sejarah menarik minat dan tidak membosankan tidak akan tercapai jika guru secara berterusan hanya mengupas apa yang ada dalam buku teks tanpa adanya rujukan tambahan dan latihan berfikir dalam kalangan pelajar (Ersis W.A dkk, 2017: 48-49).

Terlepas dari itu semua, masih banyak para guru yang belum berhasil membantu para peserta didiknya untuk mencapai tujuan pembelajaran tersebut disebabkan oleh pembelajaran yang kurang efektif. Yang mana masih banyak pembelajaran terpusat pada guru atau teacher centered learning. Tetapi ada juga yang sudah menerapkan sistem pembelajaran terpusat pada peserta didik. Contohnya di Program Studi Pendidikan Sejarah FKIP Universitas Lambung Mangkurat. Heri Susanto dan Helmi Akmal (2019: 7-8) menjelaskan Bahwa Pembelajaran dalam mata kuliah ini menggunakan pendekatan student centered learning, dengan demikian dosen berperan sebagai fasilitator, meliputi:

1. Diagnotician (mediagnose kemampuan mahasiswa) Pada fase ini seorang dosen mengidentifikasi atau mengkaji kemampuan mahasiswa.

2. Challenger (membuat tantangan) Mahasiswa tidak selalu mampu mendorong dirinya untuk belajar dan berpikir aktif. Tutor harus bisa membuat tantangan agar mahasiswanya mau mencoba strategi berpikir yang baru.

3. Activator (mengaktifkan mahasiswa) Terkadang mahasiswa sudah memiliki pengetahuan, strategi pembelajaran dan alur berpikir, tapi tidak mampu menggunakannya secara optimal. Maka tugas seorang tutor adalah membuat mahasiswa aktif menggunakan hal tersebut secara efektif melalui metode seperti brain-storming atau curah pendapat.

4. Monitoring (memonitor perkembangan mahasiswa) Setiap mahasiswa memiliki kemampuan yang berbeda-beda dalam menerima dan mengikuti proses pembelajaran. Oleh karena itu seorang tutor harus bisa melihat progres dari tutorial secara keseluruhan, dan individu-individu mahasiswa untuk dapat menentukan tindakan.

5. Evaluating (mengevaluasi hasil pembelajaran) Evaluasi terhadap proses pembelajaran meliputi assessment of student participation in PBL by facilitator, self assessment dan peer assessment. Assessment of student participation in PBL by facilitator akan menjadi dasar pemberian nilai untuk komponen proses, sedangkan evaluasi yang lain (self assessment dan peer assessment) akan menjadi bahan evaluasi perkembangan mahasiswa. 
Menurut Jenny K. Matitaputty (2016: 185) Proses pembelajaran pada dasarnya adalah sebuah proses komunikasi yang edukatif di antara pendidik dan peserta didik. Pendidik bertugas untuk membantu dan membimbing peserta didik sehingga ia mampu menjadi anggota masyrakat yang baik sesuai dengan tujuan pendidikan dan pengajaran. Adapun Pembelajaran yang efektif menurut Mulyasa yang dimuat dalam (Heri Susanto, 2014:71) ditandai dengan sifatnya yang menekankan pada pemberdayaan siswa secara aktif. Pembelajaran menekankan pada penguasaan pengetahuan tentang apa yang dikerjakan, tetapi lebih menekankan pada internalisasi, tentang apa yang dikerjakan sehingga tertanam dan berfungsi sebagai muatan nurani dan hayati serta dipraktekkan dalam kehidupan oleh peserta didik.

Pembelajaran efektif juga akan melatih dan menanamkan sikap demokratis bagi siswa. Lebih dari itu pembelajaran efektif menekankan bagaimana agar peserta didik mampu belajar dengan cara belajarnya sendiri. Melalui kreativitas guru, pembelajaran di kelas menjadi sebuah aktivitas yang menyenangkan. Perwujudan pembelajaran efektif dan memberikan kecakapan hidup kepada peserta didik. Maka dari itu, guru dituntut untuk kreatif dan inovatif dalam melaksanakan kegiatan pembelajaran di kelas, khususnya dalam memilih model pembelajaran. emilihan model pembelajaran yang tepat sangatlah penting agar tujuan pembelajaran dapat tercapai. Meskipun tujuan pembelajaran dirumuskan dengan baik, materi yang dipilih sudah tepat, jika model pembelajaran yang dipergunakan kurang memadai mungkin tujuan yang diharapkan tidak tercapai dengan baik.

Jadi, model pembelajaran merupakan salah satu komponen pembelajaran yang penting dan sangat menentukan dalam keberhasilan proses pembelajaran. Model pembelajaran yang seharusnya merupakan interaksi guru dengan peserta didik, serta interaksi antar peserta didik yang akan membentuk sinergi yang saling menguntungkan semua anggota (Anita Lie, 2008:33). Supaya pembelajaran sejarah dapat menghasilkan hasil yang optimal, hendaknya guru harus pandai memilih model pembelajaran yang mampu melibatkan peserta didik berperan aktif dalam proses pembelajaran. Oleh karena itu, bagaimanapun tepat dan baiknya bahan ajar sejarah yang ditetapkan belum menjamin akan tercapainya tujuan pendidikan, dan salah satu faktor penting untuk mencapai tujuan tersebut adalah proses pembelajaran yang lebih menekankan pada keterlibatan peserta didik secara optimal. Sejumlah model pembelajaran telah diterapkan di berbagai sekolah untuk meningkatkan kualitas proses pembelajaran.

Namun, mengingat adanya variasi tujuan yang ingin dicapai, adanya lingkungan belajar yang berlainan, keadaan peserta didik yang berbeda, karakteristik materi yang berbeda maka tidak dapat disusun suatu model pembelajaran yang cocok untuk semua 
jenis kegiatan pembelajaran. Di dalam proses pembelajaran, guru harus memiliki strategi agar peserta didik bekerja secara efektif dan efisien, tepat pada tujuan yang diharapkan. Banyak model pembelajaran yang dapat digunakan dalam pembelajaran sejarah tetapi tidak setiap model pembelajaran dapat diterapkan dalam setiap materi sehingga pemilihan model pembelajaran sangatlah penting guna mencapai tujuan pembelajaran. Oleh karena itu, sebelum pelaksanaan kegiatan pembelajaran diperlukan pemikiran yang matang dalam pemilihan model pembelajaran yang tepat untuk suatu kompetensi dasar yang akan disajikan (Tri Hartoto, 2016: 133).

\section{MODEL PEMBELAJARAN INOVATIF}

Satu diantara ciri masyarakat modern adalah selalu ingin terjadi perubahan yang lebih baik (improvement oriented). Hal ini tentu saja menyangkut berbagai bidang, tidak terkecuali bidang pendidikan. Komponen yang melekat pada pendidikan diantaranya adalah kurikulum, guru dan peserta didik. Dalam proses pembelajaran peran guru sangatlah urgen karena guru yang menentukan ketercapaian tujuan pembelajaran. Tuntutan perubahan paradigma dalam pembelajaran telah ditegaskan pada beberapa aturan antara lain:

1. Undang-undang Sistem Pendidikan Nasional No 20 Tahun 2003 pasal 4 ayat 4 menegaskan bahwa "Pendidikan diselenggarakan dengan memberi keteladanan, membangun kemauan, dan mengembangkan kreativitas siswa dalam proses pembelajaran"

2. Pendidikan diselenggarakan sebagai suatu proses pembudayaan dan pemberdayaan siswa yang berlangsung sepanjang hayat (UU no 20/2003: Sisdiknas, ps 4, ayat 3).

3. Proses pembelajaran pada satuan pendidikan diselenggarakan secara interaktif, inspiratif, menyenangkan, menantang, memotivasi siswa untuk berpartisipasi aktif, serta memberikan ruang yang cukup bagiprakarsa,kreativitas, dan kemandiriansesuai dengan bakat, minat, dan perkembangan fisik serta psikologis siswa (PP 19/2005: Standar Nasional Pendidikan, ps 19, ayat 1)

Dengan berpijak pada aturan-aturan di atas, maka pembelajaran yang dilaksanakan di sekolah harus memfasilitasi peningkatan mutu pendidikan yang dalam hal ini dijabarkan pada peningkatan mutu pembelajaran pada setiap mata pelajaran. Dalam paradigma baru pendidikan, tujuan pembelajaran bukan hanya untuk merubah perilaku peserta didik, tetapi membentuk karakter dan sikap mental profesional yang berorientasi pada global mindset. Fokus pembelajarannya adalah 
pada 'mempelajari cara belajar' (learning how to learn) dan bukan semata mempelajari substansi mata pelajaran.

Sedangkan pendekatan, strategi dan metoda pembelajarannya adalah mengacu pada konsep konstruktivisme yang mendorong dan menghargai usaha belajar peserta didik dengan proses inkuiri \& discovery learning. Dalam hal ini peserta didik sebagai stakeholder akan terlibat langsung dengan masalah, dan tertantang untuk belajar menyelesaikan berbagai masalah yang relevan dengan kehidupan mereka (Nurdyansyah \& Eni Fariyatul Fahyuni, 2016: 17-18).

Istilah model pembelajran amat dekat dengan strategi pembelajaran menurut Sofan Amri (2013) yang dimuat dalam (Nurdyansyah \& Eni Fariyatul Fahyuni, 2016: 19) mendefinisikan strategi, metode, pendekatan dan teknik pembelajaran antara lain sebagai berikut:

1. Strategi pembelajaran adalah seperangkat kebijaksanaan yang terpilih, yang telah dikaitkan dengan faktor yang menentukan warna atau strategi tersebut, yaitu: a) pemilihan materi pelajaran (guru dan peserta didik); b) penyaji materi pelajaran (perorangan atau kelompok); c) cara menyajikan materi pelajaran (induktif atau deduktif, analitis atau sintesis, formal atau non formal); dan d) sasaran penerima materi pelajaran (kelompok, perorangan, heterogen atau homogen)

2. Pendekatan pembelajaran adalah jalan atau arah yang ditempuh oleh guru atau peserta didik dalam mencapai tujuan pembelajaran dilihat bagaimana materi itu disajikan.

3. Metode pembelajaran adalah cara mengajar secara umum yang dapat diterapkan pada semua mata pelajaran, misalnya mengajar dengan metode ceramah, ekspositori, tanya jawab, penemuan terbimbing dan sebagainya.

4. Teknik mengajar adalah penerapan secara khusus atau metode pembelajaran yang telah disesuaikan dengan kemampuan dan kebiasaan guru, ketersediaan media pembelajaran serta kesiapan peserta didik. Misalnya teknik mengajarkan perkalian dengan penjumlahan berulang dan atau dengan teknik yang lainnya.

\section{MODEL PEMBELAJARAN BERDASARKAN TEORI}

1. Model Interaksi Sosial

Model ini didasari oleh teori belajar Gestalt (field theory). Model interaksi sosial menitikberatkan hubungan yang harmonis antara individu dengan masyarakat (learning to life together). Pokok pandangan Gestalt adalah objek atau peristiwa tertentu akan dipandang sebagai suatu keseluruan yang 
terorganisasikan. Makna suatu objek/peristiwa adalah terletak pada keseluruhan bentuk (gestalt) dan bukan bagian-bagiannya. Pembelajaran akan lebih bermakna bila materi diberikan secara utuh, bukan bagian-bagian.

2. Model Pemrosesan Informasi

Model ini berdasarkan teori belajar kognitif dan berorientasi pada kemampuan siswa memproses informasi. Pemrosesan informasi merujuk pada cara menerima stimuli dari lingkungan dengan mengorganisasi data, memecahkan masalah, menemukan konsep dan menggunakan simbol verbal dan visual. Menurut Piaget perkembangan kognitif individu meliputi empat tahap, yaitu: a) sensory motor; b) pre operational; c) concrete operational; dan d) formal operational.

3. Model Personal (Personal Models)

Model ini bertitik dari teori Humanistik dan juga berorientasi pada individu dan perkembangan keakuan. Tokoh humanistik adalah Abraham Maslow (1962), R. Rogers, C.Buhler, dan Arthur Comb. Menurut teori ini, guru harus berupaya menciptakan kondisi kelas yang konduktif, agar peserta dididk merasa bebas dalam belajar dan mengembangkan dirinya, baik emosional maupun intelektual.

4. Model Modifikasi Tingkah Laku (Behavioral)

Implementasi dari model modifikasi tingkah laku ini adalah meningkatkan ketelitian pada anak, guru selalu perhatian terhadap tingkah laku Peserta didik, modifikasi tingkah laku anak yang kemampuan belajarnya rendah dengan memberi reward, sebagai reinforcement pendukung dan penerapan prinsip pembelajaran individual (individual learning) terhadap penbelajaran klasikal (Nurdyansyah \& Eni Fariyatul Fahyuni, 2016: 25-33).

\section{MODEL PEMBELAJARAN CTL (COENTEXTUAL TEACHING AND LEARNING) DALAM PEMBELAJARAN SEJARAH}

Menurut Depdiknas,2003:5 (dalam Dharma Kesuma,2009:58) Contextual Teaching and Learning adalah konsep belajar yang membantu guru mengaitkan antara materi yang diajarkan dengan situasi dunia nyata dan mendorong siswa membuat hubungan antara pengetahuan yang dimilikinya dengan perencanaan dalam kehidupan mereka sehari-hari. Menurut Johnson (dalam Hosnan, 2014: 268) menyatakan bahwa CTL adalah sebuah proses pendidikan yang bertujuan menolong para siswa melihat makna didalam materi akademik yang mereka pelajari dengan cara menghubungkan subjek-subjek akademik dengan konteks dalam kehidupan keseharian mereka, yaitu dengan konteks keadaan pribadi, sosial, dan budaya mereka. 
Berdasarkan uraian di atas dapat disimpulkan bahwasanya model Contextual Teaching and Leraning merupakan strategi pembelajaran yang menekankan pada proses keterlibatan siswa dalam proses belajar mengajar dengan cara membantu siswa memahami materi yang diajarkan dan mengaitkan antara pengetahuan yang dimilikinya dengan konteks kehidupan sehari-hari. Dari konsep di atas terdapat tiga hal yang harus dipahami:

1. CTL menekankan kepada proses keterlibatan peserta didik untuk menemukan materi, artinya proses belajar diorientasikan pada proses pengalaman secara langsung,

2. CTL mendorong agar peserta didik dapat menemukan hubungan antara materi yang dipelajari dengan situasi kehidupan nyata, artinya peserta didik dituntut untuk dapat menangkap hubungan antara pengalaman belajar disekolah dengan kehidupan nyata, Hal ini sangat penting, sebab dengan dapat mengkorelasikan materi yang ditemukan dengan kehidupan nyata, bukan saja bagi peserta didik materi itu akan berfungsi secara fungsional, akan tetapi materi yang dipelajarinya akan tertanam erat dalam memori peserta didik, sehingga tidak akan mudah dilupakan.

3. CTL mendorong siswa untuk dapat menerapkannya dalam kehidupan, artinya CTL bukan hanya mengharapkan peserta didik dapat memahami materi yang dipelajarinya, akan tetapi bagaimana materi pelajaran itu dapat mewarnai perilakunya dalam kehidupan sehari-hari ( Dharma Kesuma,2009;59).

Pembelajaran Contextual Teaching and Learning (CTL) sebagai suatu model pembelajaran yang memusatkan pembelajaran pada peserta didik serta memberi fasilitas kegiatan belajar peserta didik untuk mencari, mengelolah, dan menemukan pengalaman belajar yang terkait dengan kehidupan nyata melalui keterlibatan aktivitas peserta didik dalam mencoba, melakukan, dan mengalami sendiri. Dengan demikian, pembelajaran tidak sekedar dilihat dari sisi produk, akan tetapi melalui proses. Menurut Priyatni (dalam Hosnan, 2014: 278) karakteristik dalam pembelajaran Contextual Teaching and Learning (CTL) adalah sebagai berikut:

1. Pembelajaran dilaksanakan dalam konteks yang autentik, artinya pembelajaran diarahkan agar peserta didik memiliki keterampilan dalam memecahkan masalah dalam konteks nyata atau pembelajaran diupayakan dilaksanakan dalam lingkungan yang alamiah (Learning in real life setting).

2. Pembelajaran memberikan kesempatan kepada peserta didik untuk mengerjakan tugas-tugas yang bermakna (meeaningful learning).

3. Pembelajaran dilaksanakan dengan memberikan pengalaman bermakna kepada peserta didik melalui proses mengalami (learning by doing). 
4. Pembelajaran dilaksanakan melalui kerja kelompok, berdiskusi, dan saling mengoreksi (learning in a group)

5. Kebersamaan, kerjasama saling memahami dengan yang lain secara mendalam merupakan aspek penting untuk menciptakan pembelajaran yang menyenangkan (learning to know each other deeply)

6. Pembelajaran dilaksanakan secara aktif, kreatif, dan mementingkan kerja sama (learning to ask, to inquiry, to work together ).

7. Pembelajaran dilaksanakan dengan cara yang menyenangkan (learning as an enjoy activity).

Dalam pembelajaran kontekstual, tugas guru adalah membantu peserta didik mencapai tujuannya. Tugas guru mengelola kelas sebagai sebuah tim yang bekerja bersama untuk menemukan sesuatu yang baru bagi anggota kelas (siswa). Ciri khas CTL ditandai oleh tujuh komponen utama, yaitu 1) Constructivism; 2) Inkuiri; 3) Questioning; 4) Learning Community; 5) Modelling; 6) Reflection; dan 7) Autthentic Assesment. Pendekatan CTL merupakan pembelajaran yang memungkinkan peserta didik menerapkan dan mengalami apa yang sedang diajarkan dengan mengacu pada masalah-masalah dunia nyata, sehingga pembelajaran menjadi lebih menyenangkan. Peserta didik menggunakan pengalaman dan pengetahuannya untuk membangun pengetahuan baru.

Selanjutnya memanfaatkan kembali pemahaman pengetahuan dan kemampuannya itu dalam berbagai konteks di luar sekolah untuk menyelesaikan masalah dunia nyata yang kompleks, baik secara mandiri maupun dengan berbagai kombinasi dan struktur kelompok (Nurdyansyah \& Eni Fariyatul Fahyuni, 2016: 38). Sebelum melaksanakan pembelajaran dengan menggunakan CTL, tentu saja terlebih dahulu guru harus membuat desain (skenario) pembelajarannya, sebagai pedoman umum dan sekaligus sebagai alat kontrol dalam pelaksanaannya. Pada intinya pengembangan setiap komponen CTL dapat dilakukan sebagai berikut.

1. Mengembangkan pemikiran peserta didik untuk melakukan kegiatan belajar lebih bermakna apakah dengan cara bekarja sendiri, menemukan sendiri, dan mengonstruksi sendiri pengetahuan dan keterampilan baru yang harus dimilikinya.

2. Melaksanakan sejauh mungkin kegiatan inkuiri untuk semua topik yang diajarkan.

3. Mengembangkan sifat ingin tahu peserta didik melalui memunculkan pertanyaan-pertanyaan 
4. Menciptakan masyarakat belajar, seperti melalui kegiatan kelompok berdiskusi, Tanya jawab, dan lain sebagainya.

5. Menghadirkan model sebagai contoh pembelajaran, bisa melalui ilustrasi, model, bahkan media yang sebenarnya.

6. Membiasakan anak untuk melakukan refleksi dari setiap kegiatan pembelajaran yang telah dilakuakan.

7. Melakukan penilaian secara objektif, yaitu menilai kemampuan yang sebenarnya pada setiap peserta didik

Model Pembelajaran ini sangat cocok diterapkan pada pembelajaran sejarah, Dalam pembelajaran kontekstual, guru membimbing para peserta didik untuk berpikir mengaitkan peristiwa sejarah masa lalu dengan keadaan sekarang. Sebagai suatu contoh Masa ketika Indonesia memasuki periode kerajaan-kerajaan besar adalah abad emas yang patut dibanggakan. Banyak aspek kemajuan yang belum diungkap di tataran pendidikan formal. Seiring perjalanan waktu, cukup banyak memori kolektif bangsa yang justru di masa kini menjadi isu yang banyak diperbincangkan.

Sebagai contoh, konsep ekonomi maritim global, ekonomi agraris, ketahanan negara serta kemajuan taraf intelektual, menjadi beberapa tema pokok yang dahulu pernah berkembang di Nusantara di bawah kerajaan-kerajaan besar. Penekanan kekhasan suatu kerajaan merupakan modal penting dalam mewujudkan pengajaran sejarah yang kontekstual dengan kekinian. Dalam program tersebut harus tercermin penerapan dari ketujuh komponen CTL dengan jelas, sehingga setiap guru memiliki persiapan yang utuh mengenai rencana yang akan dilaksanakan dalam membimbing kegiatan belajar-mengajar di kelas.

\section{KELEBIHAN DAN KEKURANGAN MODEL PEMBELAJARAN CTL (CONTEXTUAL TEACHING AND LEARNING)}

Menurut Suprijono (dalam Wahyu Bagja Sulfemi \& Nunung Yuliani, 2019: 7576) Kelebihan pendekatan pembelajaran kontekstual adalah real world learning, mengutamakan pengalaman nyata, berfikir tingkat tinggi, berpusat pada peserta didik, peserta didik aktif, kritis dan kreatif, pengetahuan bermakna dalam kehidupan, dekat dengan kehidupan nyata, adanya perubahan prilaku, pengetahuan diberi makna, dan kegiatan bukan mengajar tetapi belajar. Selain itu keunggulan lain yakni kegiatan lebih pada pendidikan bukan pengajaran sebagai pembentukan, memecahkan masalah, peserta didik dan hasil belajar diukur dengan berbagai alat ukur, tidak hanya tes saja.

Model pembelajaran CTL memiliki beberapa kelemahan pembelajaran kontekstual antara lain, bagi guru kelas, guru harus memiliki kemampuan untuk 
memahami secara mendalam dan komperhensif tentang konsep pembelajaran kontekstual itu sendiri, potensi perbedaan individual peserta didik di kelas, beberapa pendekatan pembelajaran yang berorientasi kepada aktivitas peserta didik, dan sarana, media, alat bantu serta kelengkapan pembelajaran yang menunjang aktivitas peserta didik dalm belajar. Sedangkan bagi peserta didik yakni inisiatif dan kreatif dalam belajar, memiliki wawasan pengetahuan yang memadai dari setiap mata pelajaran, adanya perubahan sikap dalam menghadapi persoalan, dan memiliki tanggung jawab pribadi yang tinggi dalam menyelesaikan tugas-tugas.

\section{PENUTUP}

Model pembelajaran kontekstual melalui CTL (Contextual Teaching and Learning) dalam pembelajaran sejarah dapat menambah alternatif pilihan bagi guru sejarah demi mencapai tujuan pembelajaran sejarah yang seutuhnya. CTL adalah sebuah pendekatan pembelajaran aktif yang berorientasi pada pembelajaran yang berpusat pada siswa (student centered). Oleh karena itu, dalam upaya meningkatkan kualitas kognitif peserta didik, maka guru dalam melaksanakan pembelajaran harus lebih ditujukan pada kegiatan pemecahan masalah atau latihan meneliti dan menemukan Selain itu ditengah berbagi macam masalah dalam pembelajaran sejarah khususnya berkaitan dengan kurangnya rasa kebermanfaatan sejarah bagi diri peserta didik, nampaknya model pembelajaran ini sangat cocok digunakan untuk mengatasi masalah tersebut. Langkah-langkah yang ditawarkan oleh model pembelajaran ini mampu mengantarkan peserta didik pada hasil belajar sejarah yang lebih seimbang. Keseimbangan yang dimaksud adalah keterpaduan antara aspek kognitif, afektif dan psikomotorik. Namun, hal ini masih perlu dilakukan pengkuran lebih lanjut melalui penelitian eskperimen. 


\section{DAFTAR PUSTAKA}

Abbas, Ersis Warmansyah dkk. 2017. Pendidikan Sejarah, Patriotisme \& Karakter Bangsa Malaysia-Indonesia. Banjarmasin: FKIP UNLAM PRESS

Ahyani, Nur. 2013. Kemampuan Berfikir Kritis Dalam Pembelajaran Sejarah. Prosiding Seminar Nasional Pendidikan Dalam Rangka Dies Natalis Ke 37 Universitas Sebelas Maret.

Anita, lie. 2008. Cooperative Learning: Mempraktikkan Cooperative Learning di Ruang-Ruang Kelas. Jakarta: Grasindo.

Dharma Kesuma. 2009. Contextual Teaching and Learning. Yogyakarta: Rahayasa

Ekasari, Putri Nur. 2017. Pembelajaran Berbasis Nilai Pada Matapelajaran Sejarah Melalui Model Vct (Value Clarification Technique). Jurnal Sejarah dan Budaya. Vo.11, No. 2. Pendidikan Sejarah Pascasarjana, Universitas Negeri Malang.

Hartoto, Tri. 2016. Model Pembelajaran Kooperatif Tipe Group Investigation (Gi) Meningkatkan Aktivitas Dan Hasil Belajar Sejarah. Jurnal Historia Volume 4, Nomor 2.

Hosnan, M. 2014. Pendekatan Seintifik dan Kontekstual Dalam Pembelajaran Abad 21. Bogor: Ghalia Indonesia.

Nurdyansyah \& Eni Fariyatul Fahyuni.2016. Inovasi Model Pembelajaran Sesuai Dengan kurikulum 2013. Sidoarjo: Nizamial Learning Center.

Matitaputty, J.K. 2016. Model Pembelajaran Isu-Isu Kontroversial Dalam Pembelajaran Sejarah. Social Science Education Journal, Vol 3, Nomor 2. Universitas Pattimura

Sulfemi, Wahyu Bagja \& Nunung Yuliani. 2019. Model Pembelajaran Contextual Teaching And Learning (CTL) Berbantu Media Miniatur Lingkungan Untuk Meningkatkan Hasil Belajar IPS. Jurnal Ilmiah Pendidikan Ekonomi Fakultas Keguruan dan Ilmu Pendidikan Vol. 7, No. 2. Unswagati Cirebon.

Susanto, Heri \& Helmi Akmal. 2019. Media Pembelajaran Sejarah Era Teknologi Informasi (Konsep Dasar, Prinsip Aplikatif, Dan Perancangannya). Banjarmasin: Program Studi Pendidikan Sejarah Fakultas Keguruan dan Ilmu Pendidikan Universitas Lambung Mangkurat

Susanto, Heri. 2014. Seputar Pembelajaran Sejarah (Isu, Gagasan dan Strategi Pembelajaran). Banjarmasin: Aswaja Pressindo. 